\title{
THE IMPACT OF TRANSPORT INFRASTRUCTURE ON INTERNATIONAL INBOUND TOURISM - A GRAVITY MODEL FOR POLAND
}

\author{
Grzegorz Gołembski* (i) http://orcid.org/0000-0002-4007-6398 \\ Justyna Majewska** (i) http://orcid.org/0000-0002-4132-7988
}

\begin{abstract}
Background. Development of the tourism sector depends on the infrastructure and an efficient transportation system. A better transport infrastructure results in lower transportation costs and thus lower variable costs of trading, and shortens the distance between origin and destination countries, which can stimulate international tourism flows. Significant improvements in the accessibility of general transport infrastructure (road and air) in Poland within other factors have potentially their effect on foreign inbound tourism.
\end{abstract}

Research aims. The aim of this article is to determine the importance of transport infrastructure among other classical factors of a gravity model influencing foreign inbound tourism to Poland (such as geographic and economic distance from tourism origin countries, or perceived risk factors in the origin countries, like terrorism and economic crises).

Methodology. The study is based on panel data of bilateral tourism flows in the period 2008-2016 from 33 countries trading with Poland. We applied a gravity model for international tourism flows considering four different sub-panels (disaggregated by countries and time) in order to control the role of infrastructure in various data sets.

Key findings. The results show that the level of transport infrastructure development - measured both directly and indirectly - has a significant impact on foreign inbound tourism to Poland.

Keywords: foreign inbound tourism, transport infrastructure, gravity model, determinants of international tourism flows, Poland.

JEL Codes: F14, F13, L83, R15, R41

* University of Zielona Góra, Licealna 9, Zielona Góra 65-417, Poland. E-mail: grzegorzgolembski959@gmail.com

** Poznań University of Economics and Business, Al. Niepodległości 10, Poznań 61-875, Poland. E-mail: justyna.majewska@ue.poznan.pl 


\section{INTRODUCTION}

The provision of transport infrastructure is a precondition for the development of tourism (Prideaux, 2000). In many tourism studies transport is seen as a link between tourist generating and tourist destination regions that is analysed in terms of accessibility and in the context of international tourism flows. As tourism is a form of international trade, the factors explaining tourism flows are investigated with the use of gravity model (e.g. Morley et al., 2014; Fourie \& Santana, 2011, 2013; Eilat \& Einav, 2004; Matias, 2004). However, even if models of tourism flows have been developed, they are of limited role of transport. Therefore, following Khadaroo \& Seetanah (2008) there are studies that acknowledge the need for efficient transport as the main element in a successful programme of tourism development, in particular to investigate the significance of transport as a factor in destination development at country level, on the one hand, as well as management of international tourism flows, on the other. This kind of modelling allows additional to pay more attention to often underestimated relationship between exports of goods and international tourism (due to reducing transaction costs, etc.) - see e.g. Santana-Gallego et al. (2016), Majewska (2017), Majewska \& Mińska-Struzik (2012), Marrocu \& Paci (2011), Kulendran \& Wilson (2000).

The expenditure created by inbound tourists in the destination country is regarded as the export of goods and services attributable to that country (Vanhove, 2011). It is recognised that international tourism is the biggest source of export income across the world (Eilat \& Einav, 2004). The surplus of inbound tourists' expenditure over purchases of goods and services by outbound tourists adds to the gross national product. Therefore tourism is a stimulant of international trade. This relationship is reciprocal, seeing that international trade can be, and indeed is, the main driver of business tourism demand (Turner \& Witt, 2001). It is also emphasized that foreign tourists visiting a destination country contribute to the reduction of both fixed and variable costs of international trade (Santana-Gallego et al., 2016). This is due to - for example - interaction between tourists and the local economy, which allows obtaining important gratuitous information about foreign visitor's preferences, helping local producers to provide 
products demanded in international markets. Development of the tourism sector depends on the transport infrastructure and efficient communication system, which are also the necessary conditions for the development of international trade. In turn, well-developed transport infrastructure results in lower transportation costs, thus reducing variable costs of trading (Khan \& Kalirajan, 2011).

This is why it is so important from the perspective of a destination country to track changes in its inbound tourism. The changes taking place in recent years in both the global and European tourism markets provoke questions about the reasons why these changes have occurred. They inspire researchers to identify variables influencing tourist flows from origin countries to countries of travel destination. An example of these changes is the rate of growth in tourist arrivals. Export of international inbound tourism services in 2015 increased by $3.6 \%$ over the previous year, with a $4.4 \%$ increase in international tourist arrivals (UNWTO, 2016). During the four consecutive years up to 2015, international tourism grew faster than world trade in goods, raising the share of international tourism to $7 \%$ of the world's export (UNWTO, 2016). At the same time the consumer mood and thus the intensity and direction of tourism flows were influenced by violent socio-political changes, such as the revolts known as the Arab Spring, the immigration crisis in Europe, growing nationalistic sentiments, and the fear of terrorism. Simultaneously, we are observing a systematic growth in household incomes due to levelling of economic development differences between the old and new EU member countries.

These changes are also apparent in Poland. Particularly strong growth has been observed in passenger air transport. It is worth noting that in recent years Polish airports recorded the biggest increases across the EU in the number of processed passengers (10\%, and even in excess of $10 \%$ annually), strongly reflecting the activity and popularity of low-cost carriers. New directions of travel are being offered. According to the industry's on-line news and analysis service Anna. aero, in 2016 as many as 105 new airline routes were launched at the Polish airports, with Poland being recently ranked in the top thirteen countries worldwide reporting the biggest increase in the number of new routes (Sipiński, 2016; Piotrowski, 2017). We are also observing a spectacular dynamics in the development of road infrastructure, with new motorways and expressways being commissioned on an ongoing 
basis. In the period 2008-2017 the total length of motorways in Poland increased from 663 to 1634 kilometres, that is by $246 \%$. Even faster is the growth of expressways, whose total length increased from 330 kilometres in 2008 to 1851 kilometres in 2017, which amounts to a five-fold expansion (the Government's official list of motorways and expressways in the Republic of Poland, 2018).

For many years now Poland has enjoyed a surplus in the tourism trade balance (a positive difference between export and import, i.e. a greater expenditure by foreign visitors in our country compared with the expenditure by Polish tourists abroad). In 2014 this surplus amounted to EUR 1772 million, constituting 0.42\% of GDP, while in 2010 the surplus was only EUR 754 million (Eurostat Statistics Explained, 2017). This amounts a 135\% growth of the surplus in a four-year period. This surplus contributes to the growth in GDP. The statistics covering the recent years confirm the big changes that have taken place both in the structure and volume of inbound tourism to Poland from a variety of directions. The amount of expenditure by international tourists in Poland is also changing.

Hence the aim of this article is to determine the importance of transport infrastructure among other classical factors of gravity model influencing foreign inbound tourism to Poland. We took into account both EU and non-EU countries and the periods within and after the global economic crisis of a decade ago in order to control the role of transport infrastructure in various panel data sets (distinguished by countries and time). Thus we disaggregated the overall panel data into four different sub-panels.

The rest of the paper is organised as follows: section 2 deals with the methodology, including description of data collection and selection of explanatory variables in the gravity model of tourism flows. Section 3 explains the model specification for Poland and also discusses the empirical results. Section 4 provides interpretation of the model and section 5 concludes.

\section{METHODOLOGY}

Given that tourism is a form of international trade, a natural method of determining factors influencing international tourism flows is the gravity model (Khadaroo \& Seetanah, 2008), traditionally used for 
evaluating the effects of physical and economic distance between two countries on the potential of their reciprocal trade (including trade in tourism services). According to the model, the intensity of trade measured by exports or imports is directly proportional to the real national income of countries and their gross national product per capita, and is inversely proportional to the geographic distance between economic centres of the respective countries (Matias, 2004). An additional (binary) variable included in the model covers structural factors influencing trade, such as trade preference clauses and trade barriers, membership in integrating organisations, etc. (Rynarzewski \& Zielińska-Głębocka, 2006). The dependent (explained) variables in this model with respect to tourism exchange potential can be the number of tourists arriving from their countries of origin to the destination country (Poland) and expenditure by these tourists in the destination country (Poland) (Matias, 2004; Dziedzic \& Skalska, 2013).

The dependent variables as defined above can suffer from a number of limitations; consequently the findings may not reflect the reality exactly. The limitations result from imprecision of aggregated statistical data. That is:

1. Eurostat or national statistics data on tourist arrivals show the number of border crossings, which is not the same as the number of tourists. Tourists can cross the border multiple times.

2. There are no comparable statistical data on the length of stay, a factor influencing tourists' daily expenditure.

3. As is generally known, different types of tourism entail different expenditure patterns. Likewise, behaviour of different groups of tourists is explained by different variables. WTO divides tourists by purposes of travel, such as leisure, visiting relatives and friends, business, religion and others. If aggregated data are used, this may result in less precise outcomes.

Taking those limitations into account, we decided to leave out the dependent variable of tourist expenditure in the destination country. The only dependent variable evaluated was the number of tourists arriving in Poland.

In order to study bilateral tourism and trade (commodity export) flows across countries (i.e. between Poland as home country and other trading countries) by considering influencing variables, we used panel 
data of Poland and trading partners of Poland for the period 2008-2016. In order to control the results according to the importance of transport infrastructure in gravity model we divided the whole period of the analysis into two sub-periods, i.e. period within and after the global economic crisis (respectively 2008-2012 and 2013-2016). Moreover we disaggregated data into two sub-panels divided by groups of countries (EU and non-EU members). We selected 33 countries with non-zero export flows from Poland and the highest intensity of international tourist flows - countries reported in public statistics, in particular within reports on inbound tourism flows to Poland.

We used data collected by Central Statistical Office of Poland, Institute of tourism in Poland and Eurostat database. Additionally data sources come from CEPII 2018 database, United Nation World Tourism Organisation, World Trade Organisation, and World Bank 2018.

The 33 countries selected for the study were divided into two groups:

1. EU member states (Austria, Cyprus, Czech Republic, Denmark, Estonia, Finland, France, Germany, Greece, Ireland, Lithuania, Latvia, Luxemburg, Malta, Portugal, Slovakia, Slovenia, Sweden, the Netherlands, Belgium, Hungary, Great Britain, Spain, Italy).

2. Non-EU countries (USA, Canada, Japan, Belarus, China, Norway, Russia, Switzerland, Ukraine).

The literature provides numerous examples of explanatory variables that can be analysed in the gravity model (Eilat \& Einav, 2004; Khadaroo \& Seetanah, 2008; Turner \& Witt, 2001; de Vita, 2014; Morley et al., 2014; Santana-Gallego et al., 2016). The explanatory variables are divided into three groups: push forces with respect to origin countries, pull forces attracting tourists to a destination country, and variables determining cost or attractiveness of a destination country to origin country of tourists (Morley et al., 2014).

In destination located in developing countries the major pull force is the level of transport infrastructure. The literature specifically mentions the length of paved roads relative to the area of the country, and also the number of international airports and seaports (Khadaroo $\&$ Seetanah, 2008). Among other pull forces, often cited in the literature is the real national income per capita (Santana-Gallego et al., 2016; Khadaroo \& Seetanah, 2008).

Given a correlation between tourism and international trade, among push factors a significant weight is attributed to the value of trade 
between the respective countries (origin and destination) - for instance the level of exports from Poland to selected countries (Majewska, 2017; Marrocu \& Paci, 2011; Kulendran \& Wilson, 2000). A major role is also attributed to factors such as the area or the size of population of both the origin and destination country, and distance between the two countries (typically the distance between major cities in the respective countries is considered); often mentioned is the common border and, occasionally, access to the sea in the destination country (Santana-Gallego et al., 2016).

Among variables determining the costs or attractiveness of a destination country, one of the most often cited variables is the price of tourism. This refers mainly to the relation of prices in the destination country versus prices in the tourist's country of residence (Dziedzic \& Skalska, 2013). The recommended proxy for the price of tourism is the consumer price index (CPI). It is simultaneously emphasized that the price is a significant variable explaining travel to and expenditure in affluent countries (at least wealthier than the tourist's country of residence). If the destination country is poorer than the tourist's country of residence, the price does not play a significant role in explaining the amount of expenditure. Transport costs (travel from the origin to destination country) also play a significant role (Santana-Gallego et al., 2016; Khadaroo \& Seetanah, 2008). Frequently cited is the size of population in the studied countries, and the use of the same language in the origin and destination countries is sometimes mentioned (Santana-Gallego et al., 2016).

Sporadically, other variables are proposed, which does not mean that their weight is negligible. This includes the purchasing power in the respective countries expressed in US dollars, the value of retail sales, exchange rates, or substitute services prices. And finally, there are other sporadically reported but extremely important variables explaining tourism and money flows between countries. One of them is the risk of terrorism, epidemics and natural disasters, sudden whether phenomena or political disruption. It is even proposed to measure the risks on a scale from 1 to 12 (Eilat \& Einav, 2004). Related to this is another interesting variable, namely the reputation of the destination country. And last but not least, there is fashion, a variable which is elusive and difficult to measure.

Among the explaining variables cited in literature, in the case of Poland a particular role must be attributed to transport infrastructure. 
The development of this infrastructure, measured by kilometres of new motorways and expressways being added to the existing road network, and the level of transport infrastructure with special mention of the country's connection to the European transportation network, are potentially significant pull forces for the destination country, i.e. Poland. These variables also determine the cost of travel and have an impact on the destination country's attractiveness perceived by tourists in origin countries.

Apart from these transport-related variables, our gravity model includes the classic determinants of the volume of foreign inbound tourism, i.e. the distance between the destination country and origin countries, measured by the distance between the respective capital cities, the size of population of the respective countries, average income per capita in the destination country and the difference in national income per capita between the origin and destination countries, in line with Linder's hypothesis (Linder, 1961) postulating that trade between countries with similar size economies (income per capita) and demand structure is more intense (Rynarzewski \& Zielińska-Głębocka, 2006; Keum, 2010). We also decided to consider the risk factors associated with the origin countries. This includes the risk of terrorism, natural disasters or economic crises, which all constitute push forces.

The choice of the explaining variables in preference of others was mainly due to a difficulty in obtaining reliable quantitative data (e.g. transport costs, prices of transport services, retail sales).

\section{THE GRAVITY MODEL FOR POLAND}

Given the Isard's (1954) gravity concept in international economics, the general formula can be expressed as:

$$
F_{i j}=g \frac{m_{i} m_{j}}{d_{i j}^{2}},
$$

where: $F_{i j}$ is the gravitational force (trade flow) between two objects (countries) $i$ and $j ; m_{i}$ and $m_{j}$ are respective mass (economic sizes) of the two countries; $d_{i j}$ is the distance as a resistance factor between the 
two; and $g$ is the gravitational constant illustrating all other factors determining cooperation between countries.

The gravity theory for trade flows can be described in its simplest definition as follows: trade flows between two countries are proportional to the scale of their economies and inversely affected by the distance between the partners. The mass here can be expressed as opportunities, capacities, or attractions which cause the interactions (Keum, 2010, p. 544). Thus, the term of mass can be replaced by many other forms of proxies that are dependent upon the characteristics of interactions, such as economy size, population, income level, purchasing power, and so on (Isard et al., 1998).

Taking the log-linear form, the augmented version of the gravity equation for tourism flow can be expressed as follows (Morley et al. 2014):

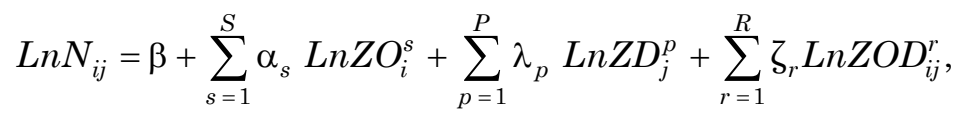

where: $N_{i j}$ denotes the tourist demand, frequently measured through the number of tourist arrivals, between the origin region $i$ and the destination region $j ; Z O^{s}$ is a vector of $s$ variables determining the push force for outbound tourists from origin $i$ (including $G D P_{i}$ per capita); $Z D^{p}$ is a vector of $p$ variables determining the pull force for inbound tourists to region $j$ (including $G D P_{j}$ per capita); $Z O D^{r}$ is a vector of $r$ variables determining the costs (or attractiveness forces) for tourists from $i$ to visiting $j$ (including $D I S T_{i j}$ ); and $B, \alpha_{s}, \lambda_{p}$ and $\zeta_{r}$ are vectors of parameters to be determined.

The independent variables include the different characteristics of the origin and destination country and may be either fixed or varying (Khadaroo \& Seetanah, 2008, p. 833). We include three additional groups of variables that are (1) relevant to the origin-destination relationship, (2) destination specific and (3) origin specific. The gravity function is specified as follows:

$$
\begin{aligned}
T R_{i j t}= & f\left(P K B_{i t}, P O P_{i t}, R I S K_{i t}, P K B_{j t}, P O P_{j t}, R O A D_{j t}, E X P_{i j t},\right. \\
& \left.D I F P K B_{i j t}, C P I_{i j t}, D I S T_{i j}, P R O X_{i j}, E U_{i j}\right)
\end{aligned}
$$

where: $i$ is used to index countries of origin, $j$ to index country of destination, that is Poland and $t$ to index time. 
The dataset includes 33 countries (Austria, Belgium, Belarus, Canada, China, Cyprus, Czech Republic, Denmark, Estonia, Finland, France, Germany, Great Britain, Greece, Hungary, Ireland, Italy, Japan, Latvia, Lithuania, Luxembourg, Malta, Netherlands, Norway, Portugal, Russia, Slovakia, Slovenia, Spain, Sweden, Switzerland, Ukraine, United States), all of them coming in as origin countries being trade partners for Poland, and the period under study is 2008-2016. The dependent and other key independent variables used are summarised in table 1 .

Table 1. Summary of variables used in the model

\begin{tabular}{|c|c|c|}
\hline Variable & Measure & Description \\
\hline$T R_{i j}$ & Tourism arrivals & $\begin{array}{l}\text { Total number of tourist arrivals per annum from } \\
\text { country } i \text { to Poland }\end{array}$ \\
\hline $\begin{array}{l}G D P_{i} / \\
G D P_{j}\end{array}$ & $\begin{array}{l}\text { Income per capita of } \\
\text { origin/destination }\end{array}$ & Average real income per capita (current USD) \\
\hline $\mathrm{POP}_{i} / \mathrm{POP}_{j}$ & $\begin{array}{l}\text { Population of origin/ } \\
\text { destination }\end{array}$ & Size of population \\
\hline$R O A D_{j}$ & Road infrastructure & $\begin{array}{l}\text { The number of kilometres of expressways and } \\
\text { motorways in destination country (Poland) }\end{array}$ \\
\hline$E X P_{i j}$ & $\begin{array}{l}\text { Export from Poland } \\
\text { to country } i\end{array}$ & $\begin{array}{l}\text { Value of exports of goods from Poland to country } i \\
\text { (current PLN) }\end{array}$ \\
\hline $\operatorname{RISK}_{i}$ & $\begin{array}{l}\text { Risks for tourists in } \\
\text { origin country }\end{array}$ & $\begin{array}{l}\text { Risks related to terrorism, natural disasters and } \\
\text { economics crisis in origin country }\end{array}$ \\
\hline$D I F G D P_{i j}$ & $\begin{array}{l}\text { Difference between } \\
\text { GDP p.c. }\end{array}$ & $\begin{array}{l}\text { Difference of real GDP per capita between two } \\
\text { trading partners }\end{array}$ \\
\hline$C P I_{i j}$ & Relative prices & $\begin{array}{l}\text { CPI ratio - CPI (year by year) of an origin country } \\
\text { in relation to CPI of the destination country } \\
\text { (Poland) }\end{array}$ \\
\hline$D I S T_{i j}$ & Distance & $\begin{array}{l}\text { Distance measured by the distance in kilometres } \\
\text { between the capital cities of the origin and desti- } \\
\text { nation country (Poland) }\end{array}$ \\
\hline $\operatorname{PROX}_{i j}$ & Accessibility (TEN) & $\begin{array}{l}\text { Dummy that takes a value } 1 \text { if origin and desti- } \\
\text { nation country is located within trans-European } \\
\text { transport networks (TEN) }\end{array}$ \\
\hline$E U_{i j}$ & EU membership & $\begin{array}{l}\text { Dummy that takes a value } 1 \text { if origin and desti- } \\
\text { nation country are members of the regional union } \\
\text { (the European Union) }\end{array}$ \\
\hline
\end{tabular}

Source: authors own elaboration. 
We estimate three panel models for different time periods: (1) first for the whole period which is 2008 and 2016, (2) the second one for the four-year period between 2008 and 2012, (3) and the last one for the four-year period between 2013 and 2016. The results of these three estimates are reported in table 2.

Table 2. Panel data estimation: period 2008-2016, 2008-2012 and 2013-2016

\begin{tabular}{|c|c|c|c|c|c|c|}
\hline \multirow[t]{2}{*}{$\begin{array}{l}\text { Indepen- } \\
\text { dent }\end{array}$} & \multicolumn{2}{|c|}{$\begin{array}{l}\text { Dependent } \\
\left(\ln T R_{\mathrm{ij}}\right) \\
2008-2016\end{array}$} & \multicolumn{2}{|c|}{$\begin{array}{c}\text { Dependent } \\
\left(\ln T R_{\mathrm{ij}}\right) \\
2008-\mathbf{2 0 1 2}\end{array}$} & \multicolumn{2}{|c|}{$\begin{array}{c}\text { Dependent } \\
\left(\ln \mathrm{TR}_{\mathrm{ij}}\right) \\
2013-2016\end{array}$} \\
\hline & Coeff. & $T$ & Coeff. & $T$ & Coeff. & $T$ \\
\hline $\ln G D P_{i}$ & $0.153^{* *}$ & 5.344 & $0.189 * *$ & 3.629 & - & - \\
\hline $\ln \mathrm{POP}_{i}$ & $0.976^{* *}$ & 38.654 & $1.021^{* *}$ & 28.142 & $0.259 *$ & 2.254 \\
\hline $\ln \mathrm{POP}_{j}$ & - & - & - & - & - & - \\
\hline $\ln R O A D_{j}$ & - & - & $0.069^{*}$ & 2.309 & - & - \\
\hline $\ln E X P_{i}$ & - & - & - & - & $0.664^{* *}$ & 6.405 \\
\hline$R I S K_{i}$ & - & - & - & - & - & - \\
\hline $\ln D I F G D P_{i j}$ & - & - & $-0.105^{*}$ & -2.251 & - & - \\
\hline $\ln C P I_{i j}$ & - & - & - & - & - & - \\
\hline $\ln D I S T_{i j}$ & $-0.723^{* *}$ & -22.132 & $-0.729^{* *}$ & -15.682 & $-0.195^{*}$ & -1.939 \\
\hline$P_{R O X_{i j}}$ & $-0.101^{*}$ & -2.850 & $-0.141^{*}$ & -3.061 & - & - \\
\hline$E U_{i j}$ & - & - & - & - & $-0.172^{* *}$ & -3.755 \\
\hline Constant & - & - & - & - & - & - \\
\hline Obs. (n) & \multicolumn{2}{|c|}{290} & \multicolumn{2}{|c|}{160} & \multicolumn{2}{|c|}{130} \\
\hline $\mathrm{R}^{2}$ & \multicolumn{2}{|c|}{0.8542} & \multicolumn{2}{|c|}{0.8773} & \multicolumn{2}{|c|}{0.8807} \\
\hline Adjusted $\mathrm{R}^{2}$ & \multicolumn{2}{|c|}{0.8511} & \multicolumn{2}{|c|}{0.8708} & \multicolumn{2}{|c|}{0.8707} \\
\hline
\end{tabular}

** and * is significance at 1 and $5 \%$ levels, respectively; forward stepwise multiple regression technique.

Source: authors own elaboration based on STATA 13 software.

We also estimated two panel models for the whole period (2008-2016) distinguishing EU and not EU member countries (table 3). 
Table 3. Panel data estimation for the EU and not EU member countries (period 2008-2016)

\begin{tabular}{|c|c|c|c|c|}
\hline \multirow{2}{*}{ Independent } & \multicolumn{2}{|c|}{$\begin{array}{l}\text { Dependent }\left(\ln T R_{i j}\right) \\
\text { EU member countries }\end{array}$} & \multicolumn{2}{|c|}{$\begin{array}{l}\text { Dependant }\left(\ln \mathrm{TR}_{i j}\right) \\
\text { Not EU member countries }\end{array}$} \\
\hline & Coeff. & $T$ & Coeff. & $T$ \\
\hline $\ln G D P_{j}$ & - & - & - & - \\
\hline $\ln P O P_{i}$ & $0.856^{* *}$ & 37.292 & $0.376^{*}$ & 2.238 \\
\hline $\ln P O P_{j}$ & $-0.087^{* *}$ & -3.8074 & - & - \\
\hline $\ln R O A D_{j}$ & & & - & - \\
\hline $\ln E X P_{i}$ & & & - & - \\
\hline$R I S K_{i}$ & - & - & $0.529^{* *}$ & 5.577 \\
\hline $\ln D I F G D P_{i j}$ & & & - & - \\
\hline $\ln C P I_{i j}$ & & & - & - \\
\hline $\ln D I S T_{i j}$ & $-0.490^{* *}$ & -16.681 & $-0.754^{* *}$ & -4.452 \\
\hline$P R O X_{i j}$ & $-0.122^{* *}$ & -4.156 & - & - \\
\hline Constant & $1518^{* *}$ & 3.823 & - & - \\
\hline Obs. (n) & \multicolumn{2}{|c|}{216} & \multicolumn{2}{|c|}{74} \\
\hline $\mathrm{R}^{2}$ & \multicolumn{2}{|c|}{0.8891} & \multicolumn{2}{|c|}{0.7797} \\
\hline Adjusted $\mathrm{R}^{2}$ & \multicolumn{2}{|c|}{0.8870} & \multicolumn{2}{|c|}{0.7563} \\
\hline
\end{tabular}

** and * is significance at 1 and $5 \%$ levels, respectively; forward stepwise multiple regression technique.

Source: authors own elaboration based on STATA 13 software.

\section{INTERPRETATION OF THE MODEL}

The results reveal many statistically significant dependencies. It has to be emphasized that the degree of variables fit to the model was very high. In the time series the fit fluctuated within the limits of $0.851-0.881$, becoming greater as the time series approached the end of the examined period. For the EU member states the fit was 0.889, while for non-EU countries it amounted to 0.779 . At the same time it must be said that absence of correlation between the explanatory variables and the dependent variable can also lead to interesting conclusions.

Confirming the assumptions accepted in the study, the road infrastructure was among statistically significant variables, with increments 
in the number of kilometres of motorways and expressways constituting a particularly important factor. A positive correlation $\left(0.069^{*}\right)$ between the road infrastructure expansion and tourist arrivals was observed especially in the sub-period 2008-2012, coinciding with large infrastructure investments connected with the organisation of EURO 2012 European Football Championship in Poland and Ukraine. This relationship was due to a fast, although still inadequate, increase in the number of expressways and motorways in Poland. Another explanatory variable examined was transport infrastructure, understood as connections between origin countries and the destination country incorporated within the European transport networks. In this case a negative correlation $\left(-0.122^{* *}\right)$ was observed with respect to a selected group of tourists, namely those originating within the European Union (panel data for the whole period and separately for the years 2008-2012). This effect can be explained by a dynamic growth of airports (including regional) offering very convenient connections, particularly within the EU, resulting in a lower impact of Trans-European road routes on the volume of foreign tourist arrivals in the destination country.

A significant positive correlation $\left(0.153^{* *}\right)$ was observed between tourist arrivals in Poland and GDP per capita in origin countries (a push factor), both in the entire study period, i.e. $2008-2016\left(0.153^{* *}\right)$ and in the years $2008-2012\left(0.189^{* *}\right)$, which suggests that the influx of foreign tourists to Poland was significantly dependant on the richer countries. Markedly, during the period of economic crisis (2008-2012) a negative correlation $\left(-0.105^{*}\right)$ was noted with respect to the variable describing the differences between GDP per capita in Poland and the country's trading partners. This supports Linder's hypothesis, whereby a greater tourism flows are observed between countries similar in terms of per capita income levels and demand patterns. This interaction was observed in the time of economic crisis, when the differences in GDP per capita between Poland and her more affluent trading partners decreased to a certain extent (Poland was then the only European country which reported a GDP growth). Therefore we may conclude that the increase in the number of tourist arrivals in Poland in the period 2008-2012 was partly due to a drop in differences between economic potentials of Poland and her trading partners.

A significant role must be ascribed to the variable determining the value of exports from Poland to origin countries. A strong correlation 
$(0.664 * *)$ between this variable and the number of tourist arrivals in Poland existed in the latter sub-period of the analysis, i.e. during post-crisis years of 2013-2016. The results confirm the following interdependencies:

1) between trade growth and development of transport infrastructure,

2) between international tourism and international trade,

3) between exports to origin countries and the number of tourist arrivals from those countries, which depend on the stage of economic cycle.

This is in line with an earlier study (Majewska, 2017) whose result were obtained with the use of an extended gravity model that included economic effects of international inbound tourism, and which constituted a modification of Helpman et al. (2008) model based on Santana-Gallego et al. (2016). The said study confirmed that a growing international inbound tourism to Poland increased the likelihood of trade relations between business entities in the respective countries being established, and contributed to the export growth between trading partners (Majewska, 2017).

Another variable examined was the distance between the origin and destination countries, measured by the geographical distance in $\mathrm{km}$ between the respective capital cities. As predicted, this correlation was negative. This was found for all time periods investigated, but was particularly evident during the first sub-period (2008-2012), when it amounted to $-0.729^{* *}$. During that time the distance to the destination country and associated cost of travel played a very significant role, whereas later it became much less important $(-0.195$ in the period 2013-2016). This correlation was especially prominent for non-EU origin countries $\left(-0.754^{* *}\right)$. The lessening strength of the inverse dependence between tourist arrivals and geographic distance from the origin to the destination country could be considered as an indirect measure describing the level of transport infrastructure development, seeing that a good infrastructure contributes to a "reduction" in geographic distance. Here it is worth citing the data published by Poland's Civil Aviation Authority (ULC) on its website, confirming a dynamic growth in the number of passengers processed at the Polish airports in regular international traffic. Between 2009 and 2017 it grew by an average $41 \%$, and with respect to individual destinations even a hundred or two hundred percent (ULC, 2018). 
We found no significant dependencies with respect to the CPI variable determining price relations between the destination and origin countries. The panel data estimations for both time periods and groups of countries (EU and non-EU) do not show an influence of this variable on the number of tourist arrivals in Poland. This is so for two reasons:

1. The CPI variable plays a significant role in explaining travel to rich countries, and Poland does not yet belong to that group.

2. In the studied period the CPI index determining the level of inflation in Poland was low and stable (in the years 2008-2012 it was $4.3 \%$ to $2.6 \%$, while in the period $2013-2016$ it fluctuated around zero) (Eurostat, 2017).

Therefore the price levels in Poland in the studied period did not affect the number of international tourist arrivals. This is a very important observation, underlining a vital role of transport infrastructure as a fundamental cost-related variable explaining the number of tourist arrivals in Poland.

A significant variable is also the size of population in origin countries relative to the population of Poland. This correlation existed and was positive for the whole period of 2008-2016 and in specific sub-periods, independent of an origin country being a member of the European Union or not. The volume of tourism flows to Poland clearly depends on the size of origin markets measured by their population size.

Membership of origin countries (Poland's trading partners) in the European Union is negatively correlated with international tourist arrivals in Poland in the latter period of the study (2013-2016). This can be explained by a growing importance and significant increase in tourist arrivals of non-EU residents, including distant markets such as USA, Japan, Canada, or China. In the period between 2011 and 2015 there was an almost 90\% increase of tourist arrivals from those countries in Poland. 2017 was a record breaking year for tourist arrivals from China - the barrier of 100000 tourists was broken. A report of the Main Statistical Office characterising non-resident arrivals to Poland reveals that the Chinese tourists spend the most of all visitors (7.8 thousand zloty on average) (POT, 2018).

And finally, the last explanatory variable tested in the study was the effect of risks existing in origin countries on the growth of international tourist arrivals in Poland (a push factor). This effect was apparent with respect to non-EU countries. During the investigated period 
the correlation between a growing risk and the increase in tourist arrivals in Poland amounted to $0.529^{* *}$, supporting the perception of Poland as a safe country, where the risks of terror attacks and natural disasters are lower than in the non-EU tourism originating countries. This factor is a stimulant of tourism flows to Poland, especially for countries whose populations are less familiar with Poland compared with EU residents.

\section{CONCLUSION}

In conclusion, we have developed model of international tourism flows between Poland and its foreign trading partners, considering transport infrastructure as a driven factor of the intensity of tourism flows that has not been previously introduced to the literature. It should be underlined that the data included and processed in the gravity model of tourism flows for Poland show a great importance of transport infrastructure, particularly passenger air transport, in the development of foreign inbound tourism to Poland. The role the transport infrastructure plays is both direct and indirect. In the direct sense this is evidenced in a declining strength of the inverse dependence between tourist arrivals and geographic distance. In other words, the distance becomes "shortened" and travel time is no longer an obstacle in getting to remote attractions offered by the destination country (owing to the development of regional airports). A direct effect is also a high growth in the number of tourist arrivals from outside Europe (China, Japan, USA or Canada).

Indirectly, transport infrastructure improvements have an indisputable impact on growth of exports from Poland. This growth is in turn strongly correlated with the number of tourist arrivals in Poland. There exists, interestingly, a negative correlation between the expansion of road infrastructure and the volume of tourism flows from EU countries. This is mainly due to the development air transport infrastructure. Passenger air transport is a viable alternative for the road transport, contributing to the dynamic growth of international inbound tourism. In general terms, we might say that the development of road infrastructure supports the growth of export which is correlated with the growth of tourist arrivals, which in turn stimulates the development of air transport infrastructure. 
Other data appear to be more control variables explaining the development of inbound tourism to Poland. There is a positive dependence between GDP per capita in origin countries and tourist arrivals in Poland. It means that Poland is visited mostly by more affluent tourists. The price relations between the destination and origin countries do not play a significant role. And finally, the number of tourist arrivals form a particular direction depends on the population size in the origin country. The general conclusion is that we must take maximum advantage of the findings afforded by the gravity model herein, given that Poland is perceived as a low risk country (in terms of terrorism and disasters), and this constitutes a special value in today's unstable world.

Moreover, based on the results of the study we determined policy implications. As there is strong positive relationship between transport development and tourism flows, as well as between commodity export (which is a proximate for transport infrastructure development) and tourism flows it is recommended to integrate transportation policies into tourism planning. As for the effectiveness of such planning a broad participation of different groups of interest is essential to allow policy makers developing an integrated and efficient transport system which is sustainable from social, economic and environmental points of view, including development of a land management regime to avoid misuse of land (Khadaroo \& Seetanah, 2008).

Furthermore, due to the rapid development of transport infrastructure and directions of tourist travels becoming more widespread what is in line with the development (taking into account the type of means of transportation and other push and pull factors of both tourist destinations and countries of tourists' origin), it is necessary to indicate an adequate strategy of promotional activities on foreign tourist markets. Tourism gravity models may be helpful in this matter as they include transport infrastructure what has not been previously used in the management of tourism in Poland. Compression of time and space resulting from the development of transport infrastructure in tourism, which can be captured by such gravity models, is also a premise for the location of airports and airport management (directions and intensity of specific connections).

As gravity model of tourism flows for Poland has been introduced to the literature further research should develop this issue, e.g. by comparison of gravity model results from other countries and assessing the robustness of the model under changing circumstances of the 
international economy. Thus, taking into account main limitation of the research that is data accuracy, further research is needed to confirm the findings considering longer and more precisely data sets, e.g. panel data describing transaction costs of business operating on international market. It should be also mentioned that this kind of modelling allows to pay more attention to often underestimated relationship between exports of goods and international tourism that should be further developed.

\section{REFERENCES}

CEPII (Research and Expertise on the World Economy) (2018). Interactive data 2017, http://www.cepii.fr/CEPII/en/bdd_modele/presentation.asp?id=30 (accessed: 15th March 2018).

De Vita, G. (2014). The long-run impact of exchange rate regimes on international tourism flows. Tourism Management, 45, 226-233.

Dziedzic, E. \& Skalska, T. (2013). Ekonomiczne uwarunkowania rozwoju rynku ustug turystycznych w Polsce. Warszawa: SGH.

Eilat, Y. \& Einav, L. (2004). Determinants of international tourism: A three dimensional panel data analysis. Applied Economics, 36(12), 1315-1327.

Eurostat (2017). Database, https://ec.europa.eu/eurostat/data/database (accessed: 10th Dec 2017).

Fourie, J. \& Santana, M. (2011). The impact of mega-events on tourist arrivals. Tourism Management, 32, 1364-1370.

Fourie, J. \& Santana, M. (2013). Cultural affinity and ethnic reunion. Tourism Management, 36, 411-420.

Helpman, E., Melitz, M. \& Rubinstein, Y. (2008). Estimating trade flows: Trading partners and trading volumes. The Quarterly Journal of Economics, 123, $441-448$.

Isard, W. (1954). Location theory and trade theory: short-run analysis. The Quarterly Journal of Economics, 68, 305-322.

Isard, W. et al. (1998). Methods of Interregional and Regional Analysis. Aldershot: Ashgate Publishing Co.

Keum, K. (2010). Tourism flows and trade theory: A panel data analysis with the gravity model. Annals of Regional Science, 44, 541-557.

Khadaroo, J. \& Seetanah, B. (2008). The role of transport infrastructure in international tourism development: A gravity model approach. Tourism Management, 29, 831-840. 
Khan, I.U. \& Kalirajan, K. (2011). The impact of trade costs on exports: An empirical modelling. Economic Modelling, 28(3), 1341-1347.

Kulendran, N. \& Wilson, K. (2000). Is there a relationship between international trade and international travel? Applied Economics, 32(8), 1001-1009.

Linder, S. (1961). An Essay on Trade and Transformation. Stockholm: Almqvist \& Wiksells.

Majewska, J. \& Mińska-Struzik, E. (2012). In Search of the Relationship between International Tourism and Trade: Evidence from Poland, ETSG 2012 Leuven, https://www.semanticscholar.org/paper/In-search-of-the-relationship-between-international-Majewska-Mi\%C5\%84ska-Struz$\mathrm{ik} / 52 \mathrm{e} 8883 \mathrm{eb562b750b5b6d869ef2f04299ecd7adc} \mathrm{(accessed:} \mathrm{23rd} \mathrm{Nov} \mathrm{2018).}$

Majewska, J. (2017). International Trade and Tourism Flows: The Gravity Model for Poland [paper delivered at 27th International Trade and Finance Association's Annual Conference "Leading issues in international Trade and Finance," Poznań, 1st June 2017], https://www.researchgate.net/ publication/320411244_International_trade_and_tourism_flows_the_gravity_model_for_Poland (accessed: 2nd Feb 2018).

Marrocu, E. \& Paci, R. (2011). They arrive with new information: Tourism flows and production efficiency in the European regions. Tourism Management, 32(4), 750-758.

Matias, A. (2004). Economic Geography, Gravity and Tourism Trade: The Case of Portugal [paper delivered at I Congress on Tourism Economics, Universitat de les Illes Baleares, Palma, 28th-29th May 2004].

Morley, C., Rosselló, J. \& Santana-Gallego, M. (2014). Gravity models for tourism demand: Theory and use. Annals of Tourism Research, 48, 1-10.

Piotrowski, M. (2017). Polska wśród najlepszych rynków lotniczych świata! Tylu nowych tras inni moga nam zazdrościć, https://www.fly4free.pl/polska-wsrod-najlepszych-rynkow-lotniczych-swiata-tylu-nowych-tras-inni-moga-nam-zazdroscic (accessed: 4th Feb 2018).

POT (2018). Chińscy turyści wybieraja Polskę. Rekord przyjazdów pobity, https://www. pot.gov.pl/pl/nowosci/wiadomosci-z-pot/chinscy-turysci-wybieraja-polske-rekord-przyjazdow-pobity (accessed: 20th March 2018).

Prideaux, B. (2000). The role of the transport system in destination development. Tourism Management, 21, 53-63.

Rynarzewski, T. \& Zielińska-Głębocka, A. (2006). Międzynarodowe stosunki gospodarcze. Teoria wymiany i polityki handlu międzynarodowego. Warszawa: WN PWN.

Santana-Gallego, M., Ladesma-Rodríguez, F. \& Pérez-Rodríguez, J. (2016). International trade and tourism flows: An extension of gravity model. Economic Modelling, 52, 1026-1033. 
Sipiński, D. (2016). Statystyki 2015: Rekordowy rok polskich lotnisk! http://www. pasazer.com/news/29081/statystyki,2015,rekordowy,rok,polskich,lotnisk. html (accessed: 4th Feb 2018).

Turner, L.W. \& Witt, S.F. (2001). Factors influencing demand for international tourism: Tourism demand analysis using structural equation modelling, revisited. Tourism Economics, 7(1), 21-38.

ULC (Civil Aviation Authority) (2018). Statystyki i analizy rynku transportu lotniczego, http://www.ulc.gov.pl/pl/regulacja-rynku/statystyki-i-analizy-rynku-transportu-lotniczego (accessed: 15th March 2018).

UNWTO (2016). UNWTO World Tourism Barometer, vol. 14, http://cf.cdn.unwto. org/sites/all/files/pdf/unwto_barom16_03_may_excerpt_.pdf (accessed: 15th March 2018 ).

Vanhove, N. (2011). The Economics of Tourism Destinations. London: Elsevier.

World Bank (2018). World Development Indicators, http://databank.worldbank.org/ data/home.aspx (accessed: 15th March 2018).

http://ec.europa.eu/eurostat/statistics-explained/index.php/File:Travel_receipts_ and_expenditure_in_balance_of_payments,_2010\%E2\%80\%9314_YB16. png [Eurostat Statistics Explained]. 